\title{
FLANK MARGIN CAVE DEVELOPMENT IN CARBONATE TALUS BRECCIA FACIES: AN EXAMPLE FROM CRES ISLAND, CROATIA
}

\author{
JAMA TIPA »FLANK MARGIN", NASTALA V POBOČNI BREČI \\ V OBMOČJU MEŠANJA SLADKE IN SLANE VODE: PRIMER \\ Z OTOKA CRESA NA HRVAŠKEM
}

\author{
Bojan OTONIČAR ${ }^{1}$, Nenad BUZJAK ${ }^{2}$, John MYLROIE ${ }^{3}$ \& Joan MYLROIE ${ }^{3}$
}

\begin{abstract}
UDC 911.2:551.44(497.5)

Bojan Otoničar, Nenad Buzjak, John Mylroie \& Joan Mylroie: Flank margin cave development in carbonate talus breccia facies: An example from Cres Island, Croatia

Plava Grota, Cres Island, Croatia, is a flank margin cave developed in a coastal setting in talus breccia facies. The internal cave geometry of small entrances, intersecting adjacent chambers, remnant dissolutional bedrock pillars, and low arches matches diagnostic features used to separate flank margin caves from epigenic stream caves on one hand, and sea caves on the other. Plava Grota is found, along with adjacent smaller caves, solely in a breccia facies that is most probably of Pleistocene age. This breccia is comprised of clasts derived from diagenetically mature, or telogenetic, Cretaceous carbonate rocks. The clasts are loosely cemented by vadose calcite cements. The breccia facies provide a three-dimensional porosity and permeability structure that behaves hydraulically in a manner similar to the high primary porosity and permeability of young eogenetic carbonate rocks in settings such as the Bahamas or Puerto Rico, and the many flow paths found in highly-tectonized telogenetic carbonate rocks in New Zealand. Plava Grota is the first described flank margin cave from the coastal carbonate rocks of the Adriatic Sea. According to present sea-level position in relation to the cave, fresh-water springs in and adjacent to the cave, general tectonic subsidence of the area and Quaternary eustatic sea-level fluctuations, we propose the hypotheses that the cave was primarily formed during the MIS 5e sea-level highstand. Keywords: flank margin caves, Croatia, Cres Island, talus breccia, Quaternary, coastal caves.
\end{abstract}

Izvleček

UDK 911.2:551.44(497.5)

Bojan Otoničar, Nenad Buzjak, John Mylroie \& Joan Mylroie: Jama tipa "Flank margin", nastala v pobočni breči v območju mešanja sladke in slane vode: primer $z$ otoka Cresa na Hrvaškem

Jama Plava Grota na Hrvaškem otoku Cresu se je izoblikovala ob obali v pobočni breči. Relativno majhni jamski vhodi, geometrija jamskih rovov $\mathrm{z}$ dvoranami, ki jih povezujejo relativno nizki in ozki prehodi, ostanki raztopljenih stebrov prikamnine in nizki oboki predstavljajo oblike značilne za jame "Flank margin" tipa, hkrati pa jih te oblike ločijo od epigenetskih na eni, in morskih jam na drugi strani. Plava Grota se nahaja, kakor tudi sosednje manjše jame, izključno v breči, ki je verjetno pleistocenske starosti. Gradijo jo klasti, katerih izvor so bližnje diagenetsko zrele oziroma telegenetske karbonatne kamnine kredne starosti. Klaste na rahlo povezujejo vadozni kalcitni cementi. Breča predstavlja tridimenzionalno porozno in permeabilno telo, ki se obnaša $\mathrm{v}$ hidravličnem smislu podobno kot mlade eugenetske karbonatne kamnine Bahamov in Puerto Rica ali kot nekatere tektonsko močno pretrte karbonatne kamnine Nove Zelandije. Plava Grota je prva jama "Flank margin" tipa opisana v obalnih karbonatnih kamninah Jadranskega morja. Glede na položaj jame in sedanjega nivoja morske gladine, izvire sladke vode $\mathrm{v}$ jami in njeni okolici, generalno tektonsko pogrezanje območja in kvartarno eustatično nihanje morske gladine domnevamo, da se je jama prvotno oblikovala v obdobju visoke morske gladine pred okoli 130.000 do 114.000 leti (MIS 5e).

Ključne besede: jame tipa "Flank margin”, Hrvaška, otok Cres, pobočna breča, kvartar, obalne jame.

\footnotetext{
${ }^{1}$ Karst Research Institute ZRC SAZU, Titov trg 2, 6230 Postojna, Slovenia, e-mail: otonicar@zrc sazu.si

${ }^{2}$ Department of Geography, Faculty of Science, University of Zagreb Croatia, Marulićev trg 19, 10000 Zagreb, Croatia, e-mail: nbuzjak@geog.pmf.hr

${ }^{3}$ Department of Geosciences, Mississippi State University, Mississippi State, MS 39762, e-mail: mylroie@geosci.msstate.edu Received/Prejeto: 9.10.2009
} 


\section{INTRODUCTION}

Flank margin caves are so named because they develop in coastal environments by carbonate rock dissolution in the distal margin of the fresh-water lens, under the flank of the enclosing landmass (Neuendorf et al. 2005, p. 241). They have been described from carbonate islands around the world, from the Bahamas in the Atlantic (Mylroie \& Mylroie 2007) to the Mariana Islands of the Pacific (Jenson et al. 2006), to the coasts of Australia (Mylroie \& Mylroie 2009) and New Zealand (Mylroie et al. 2008a), as well as from carbonate coasts on continental settings such as Yucatan, Mexico (Kelley et al. 2006). Flank margin caves are part of a series of cave and karst features that form on carbonate islands and coasts. These features have been organized by the development of the Carbonate Island Karst Model (CIKM), which seeks to explain the occurrence, form, and structure of karst landforms in island settings (Mylroie \& Mylroie 2007, and references therein). Flank margin caves are the largest cave type that develops on simple carbonate islands, and as a result they have gained significant attention. The dissolutional mechanism for flank margin caves appears to be the result of three factors that act in concert. First, mixing dissolution occurs at the boundary between salt water and the overlying fresh-water lens (Back 1986), and also at the vadose zone contact with the phreatic zone at the top of the fresh-water lens (Bögli 1964). These two mixing zones are superimposed on each other at the distal margin of the lens, where the lens thins, creating an additive geochemical effect. Second, both the top of the fresh-water lens and the bottom of the fresh-water lens are density interfaces, and collect organic matter. Oxidation of this organic material produces additional $\mathrm{CO}_{2}$ to drive carbonate dissolution, and extreme organic loading can drive the system anoxic, and bring $\mathrm{H}_{2} \mathrm{~S}$ dissolutional chemistry into action (Bottrell et al. 1993). Third, the distal margin of the fresh-water lens is a region of smaller lens cross section, such that flow velocities are increased, transporting reactants in, and more importantly, products out, at a high rate (Raeisi \& Mylroie 1995). While there has been debate about which of the three factors is most important, with some favoring bacterial action on organics (Schwabe \& Carew 2006), and others implicating high flow velocities in the thinning lens (Moore et al. 2007), it is clear that the physical location in the distal margin of the fresh-water lens creates the largest dissolutional voids on carbonate islands. A complication regarding flank margin caves in active coastal regions is being able to differentiate these dissolutional caves from sea caves formed by mechanical action of wave erosion. Such differentiation is usually done by morphometric analysis of cave maps (Lace 2008; Waterstrat et al., in press).
Flank margin caves are a measure of both sea level position, as the distal margin of the fresh-water lens is at sea level, and sea level stability, as the duration of the lens at any one position helps control the size of the cave formed. Large flank margin caves have been demonstrated to form in short periods of time, in the order of $\sim 10 \mathrm{ka}$ (Carew \& Mylroie 1995), but also to survive more than two orders of magnitude longer than they take to form, 2 ma (Panuska et al. 1998). Data from the Bahamas indicate that small flank margin caves can form in as little as $3 \mathrm{ka}$ (Mylroie \& Mylroie 2007), which means they should be able to record sea level position even in places with active tectonic uplift or subsidence. Comparison of flank margin caves formed in the Bahamas with ones formed on Isla de Mona, Puerto Rico is instructive. The Bahamian caves formed during the last interglacial or MIS 5e; however, the very large Isla de Mona caves formed in the Late Pliocene prior to the rapid high-amplitude glacioeustatic sea-level changes of the Quaternary. The extraordinary large size of the Isla de Mona caves (up to $20 \mathrm{~km}$ of surveyed passage) is inferred to be a result of the fresh-water lens being stable at a single elevation longer than was possible in the Bahamas during the Quaternary (Mylroie \& Mylroie 2007).

The reconnaissance study was initiated to determine if flank margin caves had developed in the diagenetically mature, and structurally deformed, telogenetic rocks of the Adriatic coast and islands. The first attempt to apply the flank margin model to telogenetic limestones was by Proctor (1988), on coastal outcrops of Devonian limestones in southwestern England. More recently, a study on telogenetic coastal carbonate outcrops on North and South Island, New Zealand helped establish the unique signature of flank margin processes in these mature rocks (Mylroie et al. 2008a). An unexpected outcome of the field work described here was the identification of flank margin caves in a breccia facies, as opposed to the actual in situ telogenetic rock.

The initial reconnaissance reported here examines a Croatian flank margin cave, Plava Grota, on Cres Island (Fig. 1) in an active coastal zone to determine what parts of the flank margin model do or do not carry over to this Pleistocene breccia setting. Similarities and differences between known eogenetic examples and a Croatian example will help understand the fundamental processes involved in making flank margin caves. The reconnaissance also examined coastal caves and notches developed in an Upper Cretaceous carbonate setting near Martinšćica (SW coast of Cres Island) to determine if relict flank margin caves exist in the telogenetic rocks of the Adriatic region. 


\section{GEOGRAPHIC AND GEOLOGIC SETTING}

The Cres Island is one of the northern Adriatic islands south of Rijeka in Croatia surrounded by the Rijeka Bay from the North, Kvarner Bay from the West, and Kvarnerić Bay from the East (Fig. 1).

The Cres Island is the largest $\left(405.7 \mathrm{~km}^{2}\right)$ and longest $(66 \mathrm{~km})$ Adriatic island. Tectonically, the Cres Island belongs to the External Dinarides, the most external thrust unit of the Dinaric fold and thrust belt (Korbar 2009). Paleogeographically, the area corresponds to the northern part of the Cretaceous Adriatic Carbonate Platform (sensu Vlahović et al. 2005) and in the minor extent to the Eocene synorogenic carbonate platform (sensu Otoničar 2007). A regional unconformity denoted by paleokarstic surface separates these two carbonate depositional systems (Otoničar 2007).

Due to subduction of the Adria microplate below the Dinarides (Blašković 1999; Kuk et al. 2000; Weber et al. 2006), the wider area of the Kvarner Bay and adjacent mountain belts has been seismotectonically very active in post-Pliocene period (Blašković 1999). The recent activity is reflected by the relatively frequent earthquakes (Kuk et al. 2000), and by tidal notches submerged after

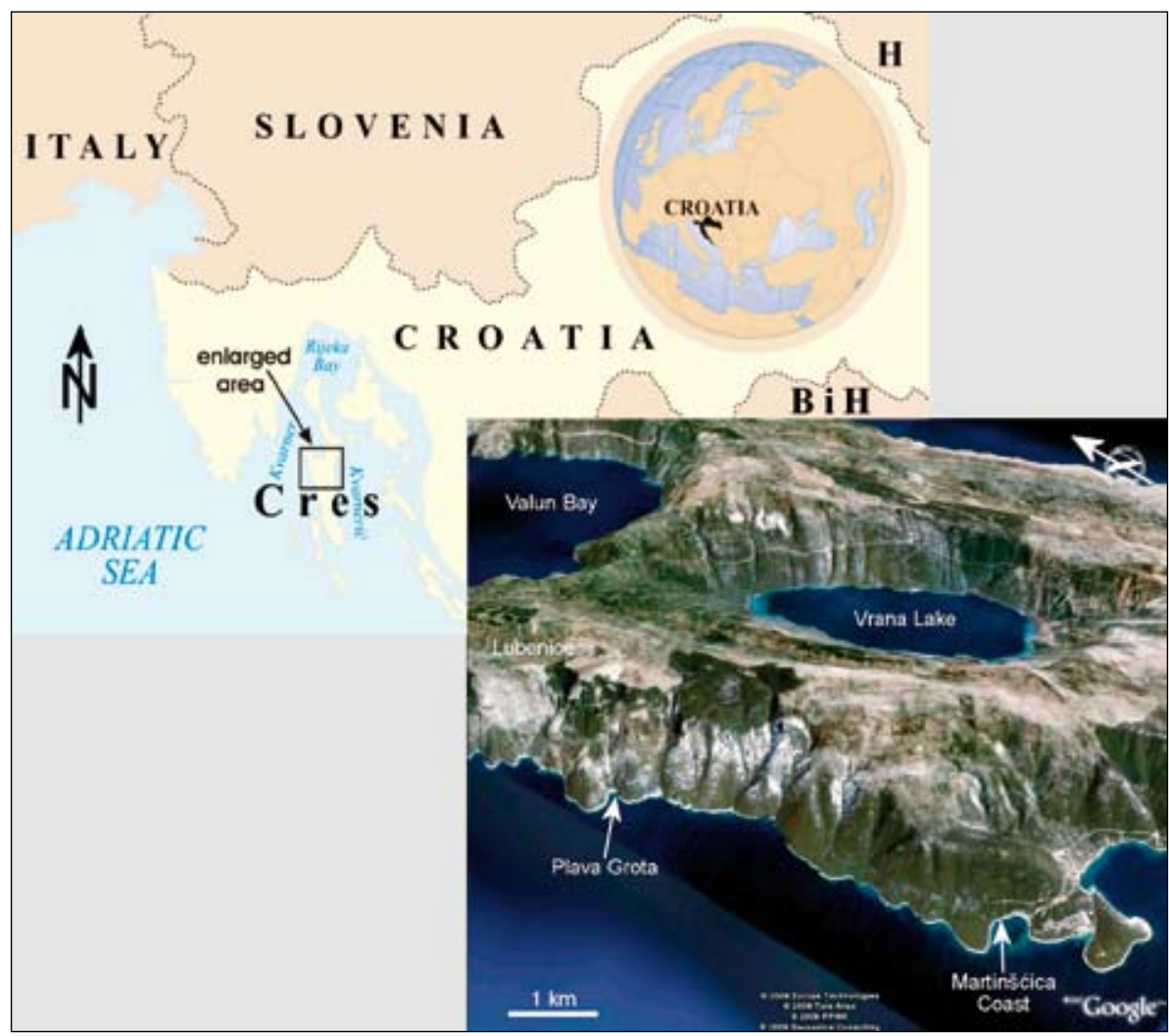

Fig. 1: Map of the northern Adriatic Sea, showing the location of Cres Island and the two study sites on the island (white arrows).
Roman-time to different depths relative to the position related to major faults (Benac et al. 2008). As a consequence of the subduction of the Dalmatian coast, the islands and Istria peninsula are submergent and sinking (e.g. Lambeck et al. 2004; Weber et al. 2006; Antonioli et al. 2007). However, Surić et al. (2009) suggest longterm tectonic uplift of $0.15-0.25 \mathrm{~mm} / \mathrm{a}$ of the area with episodic subsidence events. Uplift of more than $10 \mathrm{~mm} / \mathrm{a}$ of the SE part of Krk Island (adjacent island to Cres) is recorded by recent GPS geodetic measurements (Altiner et al. 2006).

The northern part of the Cres Island is mainly built of Cretaceous limestones and dolomites with subordinate patches of Paleogene limestones. Folded and steeply dipping carbonate beds are dissected by reverse NNW-SSE striking faults that give rise also to the specific morphology of the island. The island's interior is highly karstified. Karstic surface is commonly denoted by karrens and dolines, while subsurface features, like caves and shafts, are relatively rare but significant (Buzjak 1997; 2000). Steep slopes below the rocky cliffs (mostly structural escarpments) are covered by scree overgrown to a different degree with shrubs and trees. At the sea-level, predominately angular scree grains have been rounded by marine abrasion. Locally, scree material is cemented as a coarse-grained breccia (see below).

Specific geology, geomorphology, and hydrology of the island are represented by the $5.745 \mathrm{~km}^{2}$ large karstic fresh water Vrana Lake in the middle of the island. The lake is a typical karstic cryptodepression with mean waterlevel, at approx. $13 \mathrm{~m}$ above msl., with a flat lake bottom that lies about $40 \mathrm{~m}$ below present msl. (Schmidt et al. 2000). The water budget of the lake, which is indicative of the climate of this part of the island, is close to equilibrium, with average precipitation from years 1927 to 1961 of $1,064 \mathrm{~mm} / \mathrm{a}$ and evaporation of $1,161 \mathrm{~mm} / \mathrm{a}$ (Rubinić \& Ožanić 1992). The deepest 
part of the lake, a funnel shaped depression which penetrates the entire sediment sequence to its maximum depth of $61.3 \mathrm{~m}$ below msl. (Schmidt et al. 2000), represents a possible hydraulic connection of the lake and the deep karstic aquifer (Biondic et al. 1997). From the Late Pleistocene on, the lake and simultaneously also the underground karstic hydrology of the island was controlled by the glacioeustatic fluctuation (mainly rising) of sea-level. Regarding the sediments from Valun Bay (NW Cres Island), sea level was about $55 \mathrm{~m}$ below present during cold period approximately 16.8 to $17.8 \mathrm{ka} \mathrm{BP}$ (Schmidt et al. 2000), and so the major part of the lake's bottom was above that sea level. Subsequently, during the Late Pleistocene and Early Holocene, the Vrana was a shallow lake with fluctuating levels. After the transition stage, the present deep-water lake was established about $8.5 \mathrm{ka}$ B.C. (Schmidt et al. 2000).

All documented Roman-time or older Quaternary tidal notches of the Kvarner Bay occur below the present mean sea level. Besides some tectonically-induced differences in position of the tidal notches in most of the area of Rijeka Bay, Vinodol Channel, and Bakar Bay (northern part of the Kvarner Bay) the notches are located 50-60 $\mathrm{cm}$ below biological mean sea level (Benac et al. 2004; 2008). Similarly, according to tidal notches and archeol- ogy in the adjacent tectonically relatively stabile Istria Peninsula, mean sea level was also 50 to $60 \mathrm{~cm}$ lower in $1^{\text {st }}$ and $2^{\text {nd }}$ century A.D. than today (Fouache et al. 2004). On the other hand, Antonioli et al. (2007) claim, from the archeological evidences and models for eustatic and glacio-hydro-isostatic changes for the last 2000 years, that the Adriatic coast from the Gulf of Trieste to the southern end of Istria has tectonically subsided by $\sim 1.5 \mathrm{~m}$ since Roman times. All above mentioned tidal notches were formed during an approximately 500 year-long relative still-stand phase of the sea level during the Roman-time (Fouache et al. 2004). Benac et al. (2004) claim, that later post-Roman drowning of the notches indicates their coseismic origin with rapid regional tectonic subsidence that possibly coincided with the presumed uplift in the eastern Mediterranean in $4^{\text {th }}$ century A.D. However, Fouache et al. (2004) suggest that regional tectonicallyinduced subsidence is not acceptable because in the area of Istria no evidence of neotectonic activity has been found. In addition, tidal notches that normally comprise a deformed profile suggests relatively slow, and so not coseismic, rise of the sea-level. Notches that should be hypothetically associated with the high still-stand phase of marine isotope substage $5 \mathrm{e}$ (circa 125,000 years ago) have not been recorded in the area.

\section{RECONNAISSANCE RESULTS FROM CRES ISLAND}

\section{PLAVA GROTA}

Plava Grota (a term "Grota" derives from Italian word "Grotta" for cave; synonyms: "Plava spilja", "Škuja va Žanji") is located on the west coast of Cres Island in a small Žanja Bay just southwest of Lubenice Village (Figs. 1 and 2). The bay is opened to the southwestern winds which can produce big waves. It ends in a $100 \mathrm{~m}$ long and up to $35 \mathrm{~m}$ wide carbonate pebble beach which passes into a carbonate scree upslope. On the eastern and southeastern sides, a breccia cliff $140 \mathrm{~m}$ wide and up to $10 \mathrm{~m}$ high (above the sea-level) encloses the bay (Fig. $3)$. It can be determined as a plunging cliff that lack development of a shore platform as a result of continuous changes of sea-level.

Plava Grota is the largest of a series of small caves and abrasion notches located on the eastern sea cliff of the bay (Figs. 3-5). Similar caves are found along an inland extension of the same cliff extending north adjacent to the beach area (Fig. 3, arrows 1 and 2). All of the caves and notches are developed in the stratified, loosely-cemented, and densely-packed clast-supported carbonate

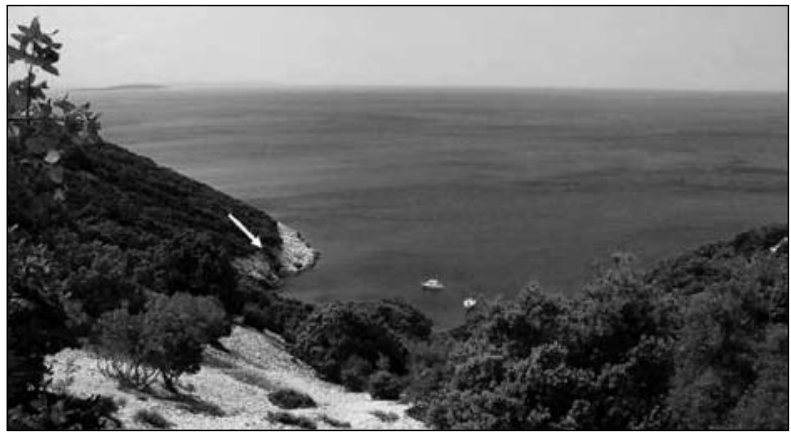

Fig. 2: The small Žanja Bay southwest of Lubenice containing Plava Grota (arrow) and related caves (Photo: J. Mylroie).

scree or talus breccia (Figs. 3-6). The breccia body is up to $15 \mathrm{~m}$ thick, covers an area of more than $2 \mathrm{ha}$, and lies unconformably over the Upper Cretaceous limestone (Figs. 3, 4 and 5B). The contact between the breccia and underlying Cretaceous limestone is erosional (Fig. 3, arrow 9 and Fig. 4). The breccia is internally stratified as demonstrated by the alternating size of the clasts (Figs. 5 and 6). The stratification is roughly parallel to the present upper slope of the breccia body with average inclination 


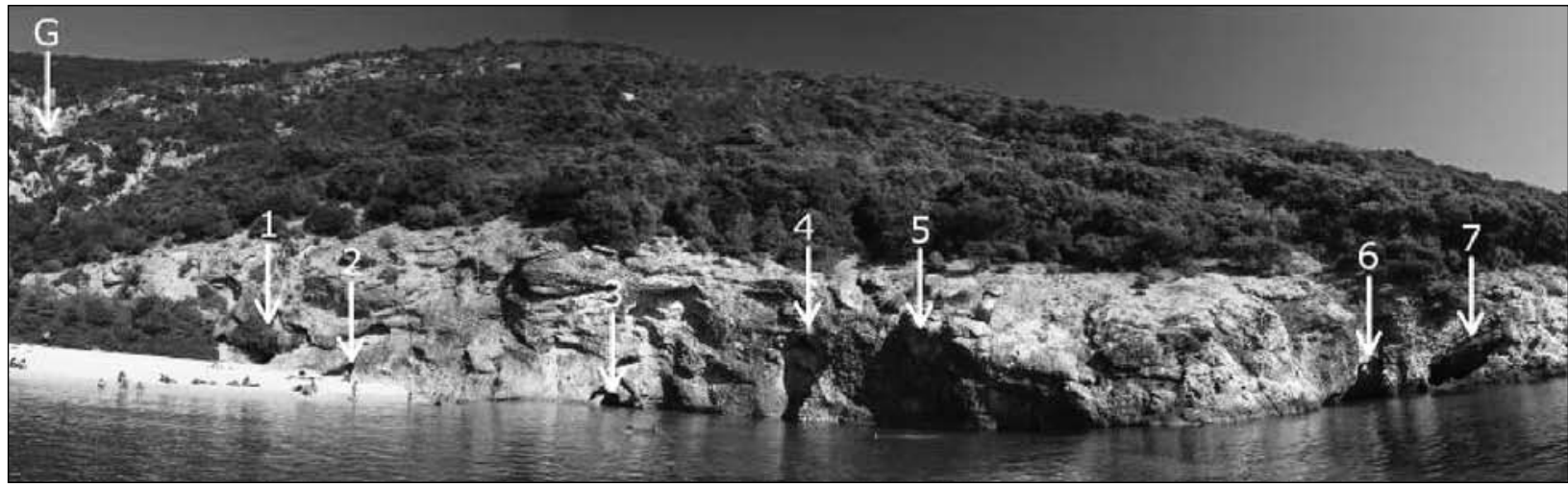

Fig. 3: The eastern sea cliff of the bay. Arrows and numbers showing Plava Grota entrances at the center (4 and 5) and right (6-8), and several caves and notches to the left (1-3), the last shown being above the beach to the left (1 and 2). G-gully at the northern erosional border of the breccia body; 4 - collapsed part of the cave with the chimney remnant (at the top of the arrow) and submerged narrow entrance to Plava Grota; 5 - traces of cliff retreat and former roof collapse above larger submerged entrance; 9 - the contact between the breccia facies and the limestone. The coast line on the figure is approximately $150 \mathrm{~m}$ long (Photo: N. Buzjak).

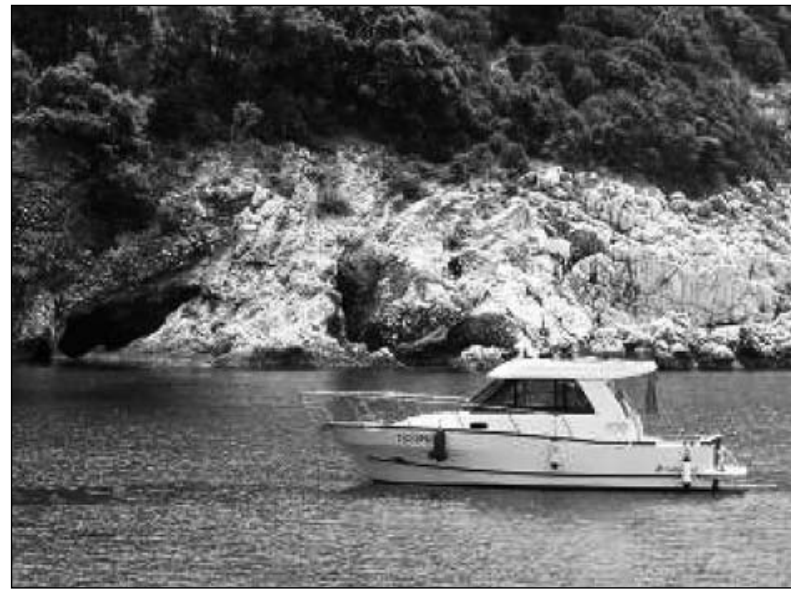

Fig. 4: Entrances to Plava Grota (arrows No. 7 and 8 on Fig. 3), slightly above current sea level, and with many remnant dissolutional bedrock pillars. This entrance morphology is typical of flank margin caves, but very different than the entrance structure of sea caves, which should be more widely opened to the sea. The contact with the breccia facies (left) and the competent limestone (right) can be seen directly above the boat roof - arrow No. 9 on Fig. 3 (Photo: J. Mylroie).

of $30^{\circ}$ (Figs. 5B, 6A and 6B). Mostly angular and predominantly limestone breccia clasts may grade from fine stone to block in size. Locally, thin intercalations of calcareous sandstone occur. On the cave walls, stratification tens of centimeters in scale and gradation of clasts are visible (Figs. 6A-C). The breccia is cemented by coarse-



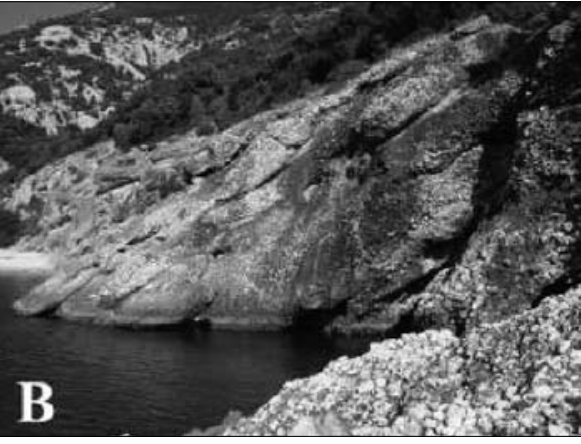

Fig. 5: Images showing the breccia facies in which all the caves at this location are developed. A - Small cave just off the beach (arrow No. 3 on Fig. 3), Flashlight in the white oval is $12 \mathrm{~cm}$ long for scale. B - Coarse-grained breccia body showing stratification roughly parallel to the present upper slope of the breccia body with average inclination of $30^{\circ}$. Cliff is up to $10 \mathrm{~m}$ high for scale (Photo A: J. Mylroie, photo B: N. Buzjak). grained equant to columnar calcite spar although needle fiber calcite precursors are still visible locally. At the site, the breccia extends at least few meters below the present mean sea level (Figs. 4-6). The stratified character of coarse-grained breccia, gradation, and dipping of the strata parallel to the slope suggesting "collective" particle movement related to some gravitational subaerial slope mass process, such as mass flows - i.e., grain flow, solifluction, etc. (see Bertran et al. 1997).

Recent retreat of the breccia body by the sea ero- 

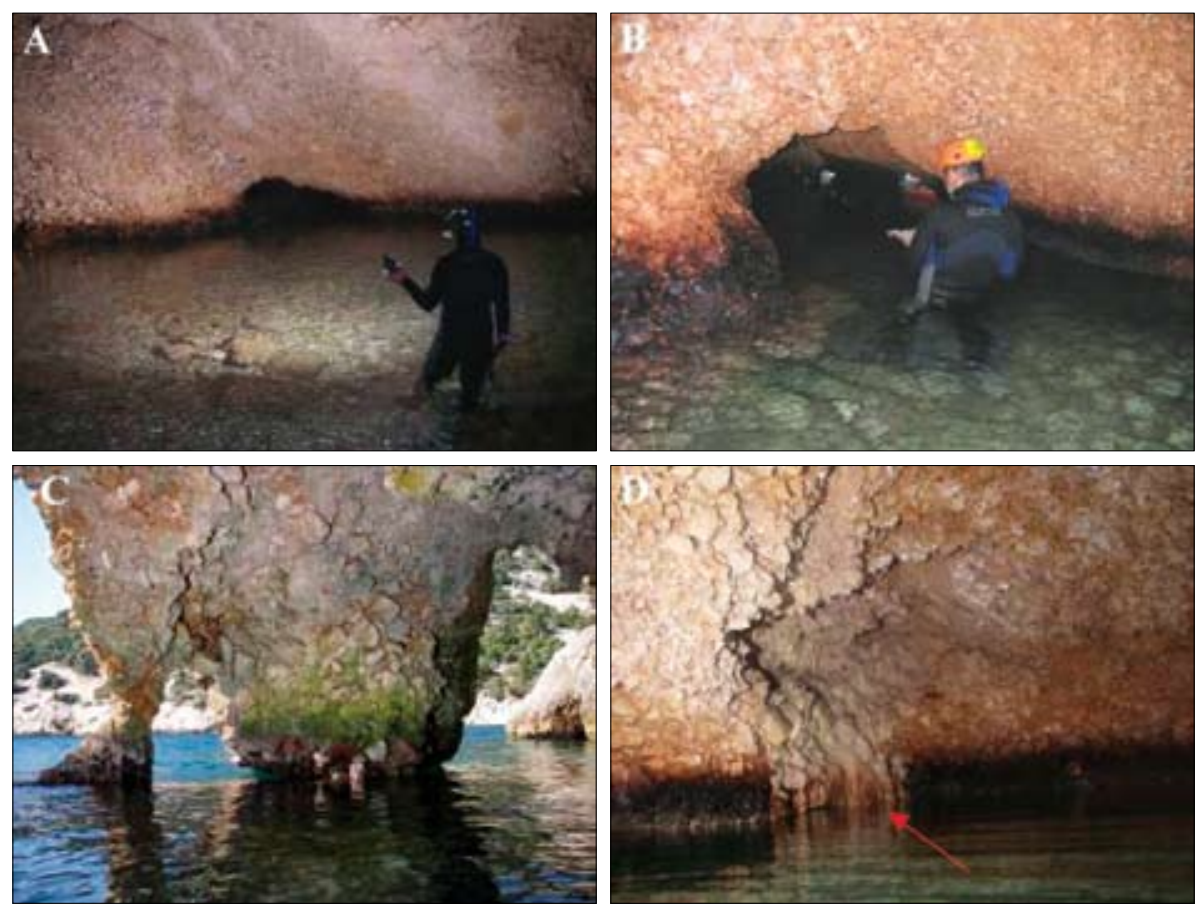

Fig. 6: Images from inside Plava Grota. A - Main chamber, with low arch leading southwest to adjacent chambers. B - Closer view of the arch passage on the image 6A. Note dissolution morphology of the arch and dark stained tidal zone. C - Remnant dissolutional/abrasional bedrock pillars at the main entrance to the cave (between arrows No. 6 and 7 on Fig. 3). D - Partly submerged flowstone (arrow) on the wall of the far northeastern corner of the main chamber. Dark stained tidal zone of all images is approximately $30 \mathrm{~cm}$ high for scale (Photos A, $C$ and D: N. Buzjak, photo B: M. Prelovšek).



Fig. 7: Map of Plava Grota. Note the relatively restricted entrances to the cave, and the many bedrock columns and adjoining chambers. Survey lines and stations are shown. Blue curved arrows indicate locations of fresh-water input to the cave. 
sion is clearly evidenced by the cliff morphology of the coast with related truncation of the breccia beddings, collapsed breccia blocks at the recent sea bottom, and truncation of the cave chambers now opened to the surface through numerous highly irregular entrances facing the sea (Figs. 3-5 and 6C). Still today especially in the southern part of the cliff with related cave entrances and "wall-less" cave chambers are exposed to the very strong southern wind or "Jugo", that can induce waves a few meters high.

A fossil tidal notch cuts the breccia body approximately $0.5 \mathrm{~m}$ below the present mean sea level. The upper surface of the breccia, above sea level, is covered by a thin dark-grey calcrete-like crust (Fig. 5B). The present intertidal zone in the cave is dark brown and reddish stained most probably because of bacteria and red algae (Fig. 6). Locally, in more illuminated parts of the cave, also green probably cyanobacteria-derived staining is observed (Fig. 6C). Although the Cretaceous unbrecciated limestone contains numerous joints, the breccia, with its calcrete cover, show no significant signs of post-depositional tectonic or slope-related processes (Figs. 3-6).

The areas of unbrecciated rock do not contain any caves at this locality, although some small fresh water springs occur along the coast from sea level to some $30 \mathrm{~m}$ above it. In the area, few relatively big underwater springs (vruljas) occur as well.

Plava Grota is a series of elongated chambers and passages (Fig. 7) that extend for $46 \mathrm{~m}$ parallel to the coast, and for $30 \mathrm{~m}$ inland. The large main chamber on the northeast half of the cave is up to $8 \mathrm{~m}$ high, $24 \mathrm{~m}$ wide, and $27 \mathrm{~m}$ long. The volume of the known cave chambers is approximately $5,100 \mathrm{~m}^{3}$, extending over an area of $858 \mathrm{~m}^{2}$. Vadose speleothems, primarily stalactites and flowstone, are found high on the east wall and ceiling of this chamber. In one place only, the flowstone extends below the mean sea level (Fig. 6D). Fresh-water discharges are located at the rear of the main chamber along the eastern wall, and at the very back of the cave to the southeast (blue curved arrows on Fig. 7). Chambers connected by low arches, with common isolated bedrock pillars define the passage morphology (Figs. 6A-C and 8). The six recorded entrances to the cave are above, below, and at sea level (Figs. 3, 4, 6 and 7). The entrances located at and above sea level are larger and more irregularly shaped (Figs. 4 and 6C) compared to those below sea level. The cave is completely developed in the above described breccia body (Figs. 3-8). The overall pattern of the cave is one of a series of interconnecting chambers that are tangential to one another (Fig. 7). The bottom of the cave is mostly covered by gravel of loose individual breccia clasts and larger, even few $\mathrm{m}^{3}$ large breccia blocks

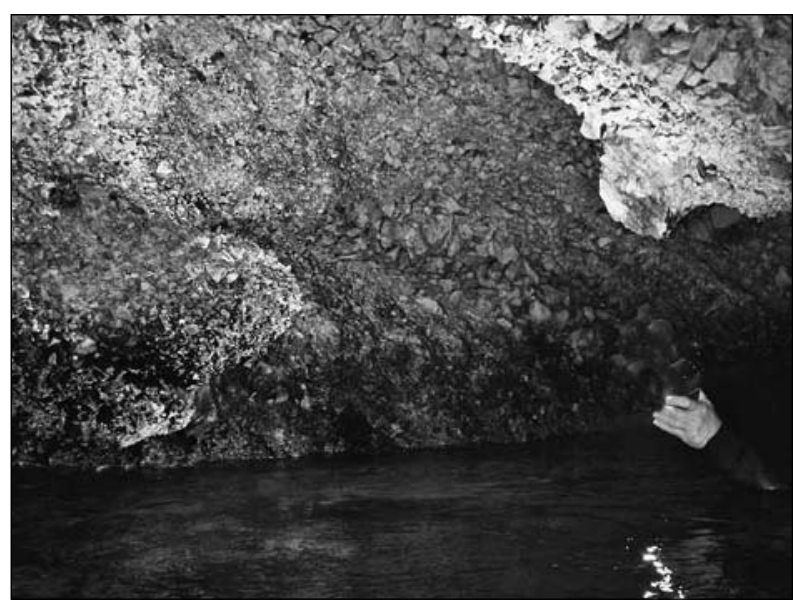

Fig. 8: Detail image of the wall rock of Plava Grota, showing its breccia characteristics and dissolutional morphology. While the wall is rough, following the clast morphology on the centimeter scale, on the meter scale the cave wall shows smooth undulation and rounding (Photo: N. Buzjak).

(Fig. 6A). On the southern side of the big chamber a beach a few meters wide with relatively well-rounded gravel occurs. The cave walls are usually rough following morphology of breccia clasts (Figs. 6 and 8) although locally more or less smoothened wall portions occur (Figs.5A and 8).

\section{MARTINŠĆICA COAST}

On the coastal outcrops of telogenetic Upper Cretaceous limestone just west of Martinšćica village in a low coastal cliff (Fig. 9), a series of cave chambers that are in the process of being breached by wave erosion occur. These small features were not mapped, but their morphology is consistent with phreatic dissolution (Fig. 10) and they may represent the initial stages of flank margin cave development. As can be seen in Figs. 9 and 10 the rock is highly fractured. The caves are at the head of a coastal embayment. These observations may allow an interpretation to be made, as will be discussed later. 


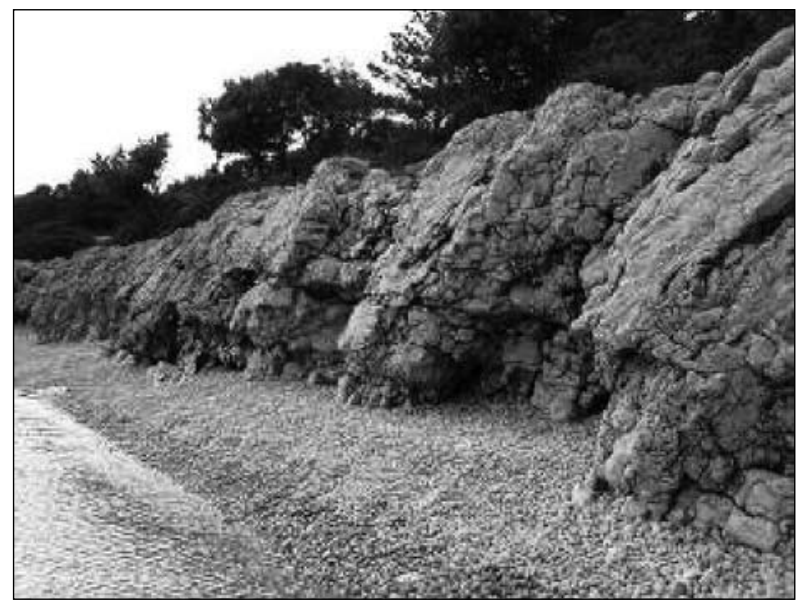

Fig. 9: Low coastal cliff at Martinšćica. Cliff is approximately $4 \mathrm{~m}$ high for scale (Photo: J. Mylroie).

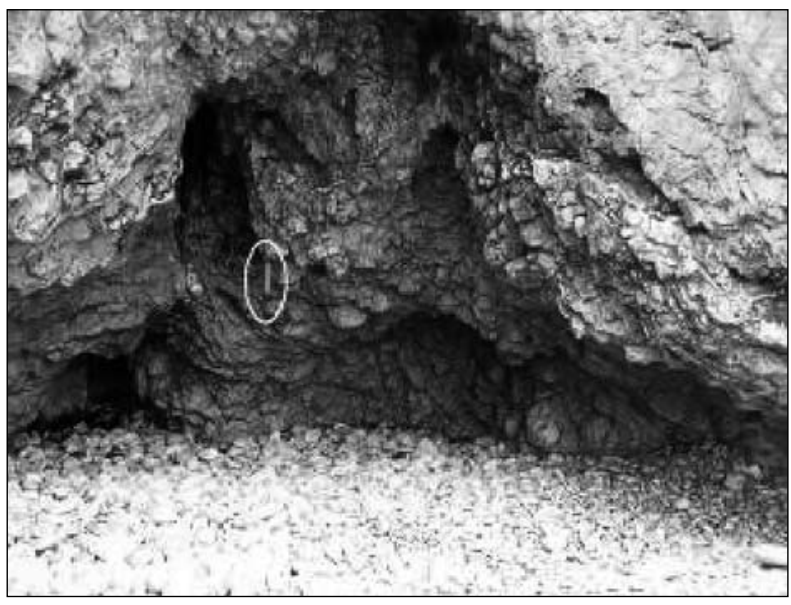

Fig. 10: Cave remnant in the sea cliff at Martinšcica. Note the cusps and pockets along the back wall, suggesting a dissolutional origin. Flashlight (encircled) is $15 \mathrm{~cm}$ long for scale (Photo: J. Mylroie).

\section{DISCUSSION}

There are a number of lines of evidence to suggest that Plava Grota is a flank margin cave. First, it has a number of entrances (Figs. 3, 4 and 7) that are very constricted relative to the size of the inner chambers and passages, which argues for a dissolutional origin and not a wave erosion origin. Second, it has several fresh-water discharge points in the back wall and sides (Fig. 7), indicating that fresh water/salt water mixing is currently possible in this setting. Third, the passage shapes and morphology (Figs. 6-8), and large chambers tangentially connected to adjunct chambers by low archways (Figs. 6A-B and 7), are consistent with those associated with flank margin caves (Labourdette et al. 2007). The location of smaller caves at the same elevation at this site with approximately equal separations between them (Figs. 3-5) is typical of flank margin cave development, often called a "beads on a string" pattern (Mylroie \& Mylroie 2007).

The observation that Plava Grota and the nearby smaller caves are developed in breccia facies, and not the adjacent competent carbonate rock, indicates that the breccia has some controlling influence on cave development. Loosely-cemented breccia clasts exposed on the cave walls suggest high porosity of the breccia and/or high dissolution of intergranular cements. Roughness of the cave walls due to projection of the breccia clasts into the cave also reflects preferential dissolution of cements and falling out of the clasts. However, it is very difficult to estimate the importance of the corrosion versus erosion in the origin of the present cave and the interweav- ing of different processes in time and space in relation to sea-level position. We suggest that at least the early phases of cave evolution was primarily dissolutionallycontrolled, as demonstrated by the morphology, shape and interconnection of the cave chambers, especially the smaller chambers where collapse modification has not occurred. During later phases, when the cave became opened to the sea by marine erosion of the breccia flank, material was also mechanically eroded and transported out of the cave, especially during storms as evidenced by the gravelly bottom of the cave and the beach with rounded pebbles on the southern side of the big chamber. Mechanical breakdown is most pronounced in the big chamber, where highest parts of the ceiling were formed by collapse, as shown by a few $\mathrm{m}^{3}$ large blocks of breccia below them. Because ceilings of some chambers now located above mean sea-level still contain characteristics of original phreatic dissolutional origin (Fig. 8), we suggest that major parts of these chambers were formed when the relative water table was above present mean sea level. Caves found along an inland extension of the cliff extending north adjacent to the beach area also require a higher relative water table for their origin. That relative water table was fluctuating after at least some parts of the cave had already been formed is evidenced by the flooded flowstone (Fig. 6D). It is possible that some channels that are recently below mean sea level are still forming and reshaping in today's mixing zone as evidenced by fresh water discharges inside the cave (Fig. 7, blue curved ar- 
rows). Solution sculptures related to corrosion processes due to episodic freshwater occurrence and mixing with seawater just below the sea-level have been reported from Y-cave of Dugi Otok, Croatia (Juračić et al. 2002).

Although this initial reconnaissance investigation has not included dating of breccia cements and submerged flowstone, we can still propose some hypothesis on the age frame of cave formation. Loosely lithified by vadose, most probably pedogenically-induced cements, the calcrete-like crust on the surface of the breccia body as well as depositional characteristics and geomorphology of the breccia body that are in accordance to recent slope, suggest relatively recent depositional and diagenetic processes of the breccia. Although the area has been tectonically quite active since the Pliocene, the breccia is tectonically practically undisturbed in contrast to Cretaceous and Paleogene carbonates of the area, what also suggests a relatively recent time of deposition. Because the breccia extends at least few meters below mean sea level, and according to the proposed depositional mechanism of the breccia, it is likely that it was formed during some past glacial period when the sea-level was lower than at present. Because in the area the Late Quaternary tectonic vs. eustatic vs. glacio-hydro-isostatic control on relative sea level (and hence the water table) is still unclear in details, it is very difficult to decide whether caves were formed during the Holocene or during some former high stand, most probably marine isotope substage (MIS) 5e some 130 to $114 \mathrm{ka}$ ago. If the northern Adriatic Islands have been really sinking during Quaternary (see Vrabec \& Fodor 2006; Benac et al. 2004; 2008) and if during Holocene eustatic sea level has never been higher than today considering also glacio-hydro-isostatic effects due to deglaciation (see Lambeck \& Chappell 2001 and Lambeck et al. 2004) than the cave should have originated during some older high-stand period. If the global sea level was approx. 4-6 $\mathrm{m}$ higher during MIS 5e than today (Overpeck et al. 2006) [in the Mediterranean typically between 3 and $10 \mathrm{~m}$ above present sea-level in tectonically stabile areas (Lambeck \& Purcell 2005; Ferranti et al. 2006)] than the sinking rate was in the range between 0.025 to $0.05 \mathrm{~mm} / \mathrm{a}$ to place the cave at present position, what is much less than average subsidence rate of approx. $0.15 \mathrm{~mm} / \mathrm{a}$ near relatively adjacent Trieste (Lambeck et al. 2004) or $0.75 \mathrm{~mm} / \mathrm{a}$ suggested by Antonioli et al. (2007) for the last 2,000 yr for NE Adriatic coasts. Although having a very high uncertainty regarding age and shoreline position Ferranti et al. (2006) suggest $0.21 \mathrm{~mm} / \mathrm{a}$ of the sinking rate for the last 125,000 yr near Triest from lagoonal deposits in boreholes. However, there is also the possibility that some uplift has occurred at times during Quaternary in the region (e.g., Altiner et al. 2006; Surić et al. 2009), which would reset the subsidence clock. According to position of submerged speleothems with depositional hiatuses that represent MIS 5a highstand records Surić et al. (2009) suggest a long term regional tectonic uplift of 0.15 to $0.25 \mathrm{~mm} / \mathrm{a}$ with episodical subsidence events generated by collision of Adria microplate with European continent. Substage 5e tidal notches if developed at all may have been destroyed during 125,000 years lasting subaerial corrosion. It is possible that the $5 \mathrm{e}$ notches of the Eastern Adriatic coast were not developed in such size than some of tectonically more stabile areas of the Mediterranean, like for example Sardinia (see Lambeck et al. 2004; Ferranti et al. 2006; Antonioni et al. 2007 and references therein).

If the cave formed during the Holocene then the relative sea level should be at least few meters higher sometime between 8.5 to $2 \mathrm{ka}$ ago than it is today. Namely, the sea-water in Valun Bay and fresh-water in Vrana Lake reached approximately present day water-level some $8.5 \mathrm{ka}$ ago (Schmidt et al. 2000) while approximately $2 \mathrm{ka}$ ago Roman time sea-level still-stand occurred (Fouache et al. 2004). In this scenario, the cave should have formed in a relatively narrow time frame. During and after this time, substantial erosion of the breccia body should have occurred. In addition, higher relative sea-level should be followed by regression and Roman time still-stand when the presently approximately $0.5 \mathrm{~m}$ below mean sea level submerged tidal notch was formed. If this scenario is valid then it might be expected that at least some remains of tidal notches related to the cave forming highstand would be preserved in the area. However, notches are exposed on coastal rocks, whereas flank margin caves are just within the coast, such that the erosion necessary to breach the flank margin caves would also necessarily remove the coastal notches (Lace 2008; Waterstrat et al. in press). Polyphase cave development should not be neglected especially because fresh-water discharges are still present in the cave and fresh and marine waters are still mixing.

The largest flank margin caves in New Zealand, at Kaikoura, are developed in a highly-tectonized carbonate unit, the telogenetic Amuri Limestone. The rock consists of fragments 10 to $20 \mathrm{~cm}$ in size (Fig. 11), not unlike a breccia facies at Plava Grota except that the blocks are in situ and not rotated or translated (Mylroie et al. 2008a). In Bahamian eogenetic rocks, Mylroie et al. (2008b) demonstrated that flank margin caves had developed in coastal breccia facies on both Crooked Island (Fig. 12A) and Rum Cay (Fig. 12B). The New Zealand situation was explained to occur as a result of the many fractures present allowing water to work across the volume of the rock, as opposed to merely in two 


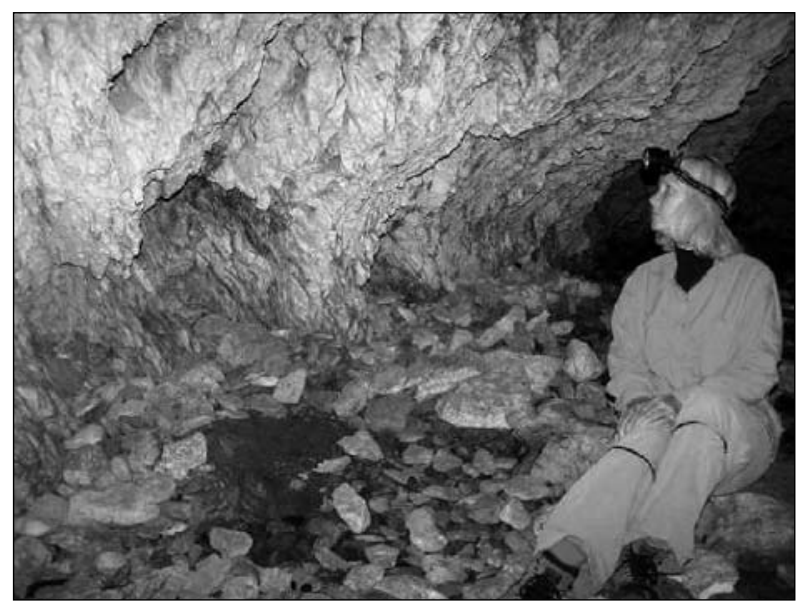

Fig. 11: Highly fractured telogenetic Amuri Limestone in Kaikoura Point Sea Cave, New Zealand, a flank margin cave. Note the uniform 10 to $20 \mathrm{~cm}$ dimensions of the majority of the breakdown fragments, representative of the highly-fractured nature of the host rock (Photo: J. Mylroie).
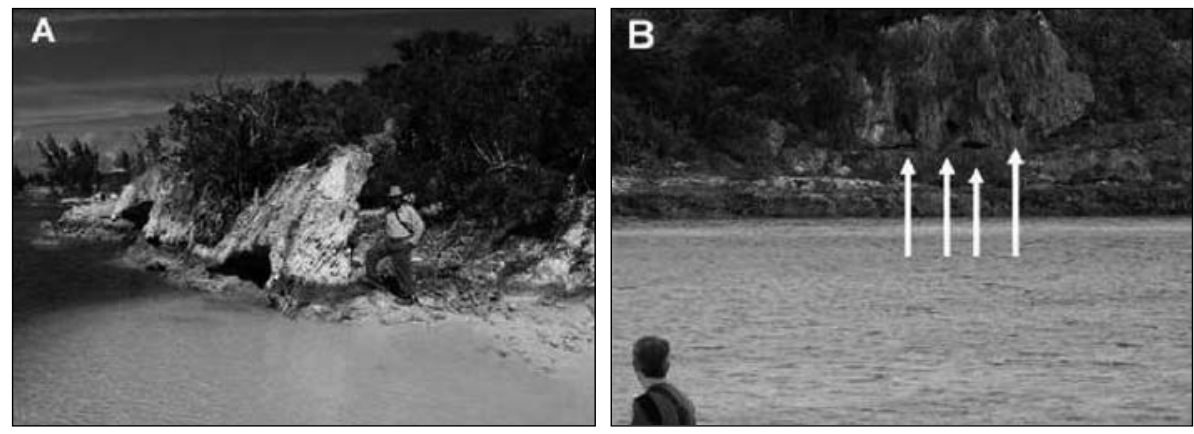

Fig. 12: Bahamian examples of flank margin cave development in breccia facies. A - The Arches, Rum Cay, Bahamas. A series of caves developed through fallen slabs and associated debris during the last interglacial sea-level highstand (MIS5e). B - Recycled Cave, Crooked Island, Bahamas. The cave developed through the fallen block and associated debris during the last interglacial sealevel highstand (MIS5e). Cave entrances indicated by arrows. Both images from Mylroie et al. (2008b).

dimensions along widely-spaced joints and bedding planes, as in most telogenetic carbonate rocks (Mylroie et al. 2008a). The breccia enclosing Plava Grota and the nearby smaller caves is a material able to host a large volume of water in a medium that also has a very high hydraulic conductivity. In that regard, the Plava Grota breccia (and the New Zealand tectonized carbonates), while made of telogenetic clasts, behaves hydraulically like a porous and permeable eogenetic carbonate rock.
The high hydraulic conductivity of the breccia attracts water from the bedrock mass behind it, resulting in a focusing of flow into the breccia unit to create discharge areas to the sea. These discharge areas are locations where fresh water and salt water mixing can occur, and where decreased lens thickness at the coast increases flow velocities. This situation mimics in many respects the coastal conditions found in the eogenetic rocks of the Bahamas and Puerto Rico, creating the unique dissolutional signature of flank margin caves.

We suggest that the catchment area of the Plava Grota discharge area is local and not related to the Vrana Lake hydrogeology. Namely, the main lithologic, structural, and morphologic lines of this part of the island run parallel to the coast and so form hydrogeologic barrier between the Vrana Lake and the coast. In addition, the main outflows of the island's aquifer are still adapted to pre-Holocene karstic hydrogeology what is reflecting in deep outflow of the lake (Biondić et al. 1997) and relatively large submarine springs, while springs adjacent to the Plava Grota are small and some of them even more than $10 \mathrm{~m}$ above the highest level of the lake. It has been demonstrated in the Yucatan that flank margin caves can form in response to isolated coastal hydrology, while deep conduit systems underflow them (Kelley et al. 2006).

The placement of flank margin caves within embayments is a result of those embayments creating a focus of ground-water flow that can enhance flank margin cave development (Stafford et al. 2004). The center of an embayment is a shorter flow path for groundwater than a subsurface route along the sides of the embayment. The potential small flank margin caves at Martinšćica are at the head of a small embayment. The embayment at Plava Grota has collected sediment which has advanced seaward, damming past discharge points and moving the active discharge point to the vicinity of Plava Grota.

\section{CONCLUSION}

Plava Grota is entirely developed in Pleistocene talus breccia with clasts derived from telogenetic carbonate rocks. It is very likely that the cave's present appearance is to a great extent the result of processes characteris- 
tic of a flank margin cave development related to MIS $5 \mathrm{e}$ obliterated by subsequent marine erosion processes and transformation in the vadose and recent mixing fresh/marine water zones. As such, it is the first flank margin cave to be described from the carbonate rocks in, and bordering, the Adriatic Sea. The restriction of the Plava Grota and the adjacent caves to the breccia facies reflects the three-dimensionality of such an aquifer, its high storage, and its high hydraulic conductivity. In that respect, as in New Zealand's telogenetic example at Kaikoura, the best flank margin cave development occurred when the telogenetic rocks (or their breccias) created a hydraulic environment comparable to that which exists in highly porous and permeable eogenetic carbonate rocks such as are found in the Bahamas and Puerto Rico.
Cres Island is in a tectonic setting, where many of the islands are actively subsiding. As a result, for flank margin caves to be found at sea level today requires that their development has been very rapid and/or a scale of tectonic subsidence has not been very distinctive following cave development. The presence of Plava Grota, with its present-day fresh-water discharges, and the small caves in agreement with modern sea level and coastal topography at Martinšćica, indicate that flank margin cave development is an active and on-going process on Cres.

Future work, e.g., dating of breccia cements, calcrete, and flowstone, is needed to determine the exact time frame of cave development. Thus, the Plava Grota could offer reliable data on relative sea-level position and/or eustatic/isostatic/tectonic evolution of the area during the Quaternary.

\section{ACKNOWLEDGMENTS}

The authors thank the Karst Research Institute ZRC SAZU for logistical assistance and support to Joan and John Mylroie for the June 2007 field work and the support of Ministry of Science, Education and Sports of Croatia, Project No. 119-1191306-1305: Geomorphological and geoecological research on Karst features in the Republic of Croatia. We thank also to Mitja Prelovšek (Karst
Research Institute ZRC SAZU) for the measuring of water quality that confirmed previous observations and assumptions about directions of present freshwater inflow and to Mike Lace for his analysis of the Plava Grota map. We are thankful to Robert Baković, Domagoj Pleše, Domagoj Tomašković and Ivana Živković from Caving Club Samobor for their assistance during the fieldwork.

\section{REFERENCES}

Altiner, Y., Marjanović, M., Medved, M. \& Lj. Rasić, 2006: Active deformation of the Northern Adriatic region: result from the CRODYN geodynamical experiment.- In: Pinter, N., Grenerczy, G., Weber, J., Stein, S. \& D. Medak (eds.) The Adria Microplate: GPS Geodesy, Tectonics and Hazards (NATO Science Series IV: Earth and Environmental Sciences). Springer, pp. 257-268, Dordrecht.

Antonioli, F., Antidei, M., Lambeck, K., Auriemma, R., Gaddi, D., Furlani, S., Orrù, P., Solinas, E., Gaspari, A., Karinja, S., Kovačić, V. \& L. Surace, 2007: Sealevel change during the Holocene in Sardinia and in the northeastern Adriatic (central Mediterranean Sea) from archaeological and geomorphological data.- Quat. Sci. Rev., 26, 2463-2486.

Back, W., Hanshaw, B.B., Herman, J.S. \& J.N. Van Driel, 1986: Differential dissolution of a Pleistocene reef in the ground-water mixing zone of coastal Yucatan, Mexico.- Geology, 14, 137-140.
Benac, Č., Juračić, M. \& I. Blašković, 2008: Tidal notches in Vinodol Channel and Bakar Bay, NE Adriatic Sea: Indicators of recent tectonics.- Marine Geology, 248, 3-4, 151-160.

Benac, Č., Juračić, M. \& T. Bakran-Petricioli, 2004: Submerged tidal notches in the Rijeka Bay NE Adriatic Sea: Indicators of relative sea-level change and of recent tectonic movements.- Marine Geology, 212, $1-4,21-33$.

Bertran, P., Hétu, B., Taxier, J.-P. \& H. van Steijn, 1997: Fabric characteristics of subaerial slope deposits.Sedimentology, 44, 1-16.

Biondić, B., Kapelj, S. \& S. Mesić, 1997: Natural traces - Indicators of the origin of the water of the Vrana Lake on Cres Island, Croatia.- Tracer Hydrology, 97, 113-120.

Blašković, I., 1999: Tectonics of part of the Vinodol Valley with the model of the continental crust subduction.- Geologia Croatica, 52, 2, 153-189. 
Bottrell, S.H., Carew, J.L. \& J.E. Mylroie, 1993: Bacterial sulphate reduction in flank margin environments: Evidence from sulphur isotopes.- In: White, B. (ed.) Proceedings of the $6^{\text {th }}$ Symposium on the Geology of the Bahamas, $11^{\text {th }}-15^{\text {th }}$ June 1992, Port Charlotte, Florida. Bahamian Field Station, 17-21, San Salvador.

Buzjak, N., 1997: Krško podzemlje otoka Cresa.- Geogr. horizont, 2, 109-117.

Buzjak, N., 2000: Collapse structures as connection between the karst surface and undergorund (examples from Croatia).- Acta carsologica, 29, 2, 65-81.

Bögli, A., 1964: Mischungskorrosion: Ein Beitrag zum Verkarstungproblem.- Erkunde, 18, 83-92. As reported in A. Bögli, 1980: Karst Hydrology and Physical Speleology.- Springer Verlag, pp. 284, New York.

Carew, J.L. \& J.E. Mylroie, 1995: Quaternary tectonic Stability of the Bahamian Archipelago: Evidence from fossil coral reefs and flank margin caves.- Quaternary Science Reviews, 14, 144-153.

Ferranti, L., Antonioli, F., Mauz, B., Amorosi, A., Dai Pra, G., Mastronuzzi, G., Monaco, C., Orrù, P., Pappalardo, M., Radtke, U., Renda, P., Romano, P., Sansò, P. \& V. Verrubbi, 2006: Markers of the last interglacial sea-level high stand along the coast of Italy: Tectonic implications.- Quaternary International, 145-146, 30-54.

Fouache, E., Faivre, S., Dufaure, J. J., Kovačić, V., Tassaux F. \& P. Tronche, 2004: Morska razina u rimsko doba na području Istre.- VAMZ, 3.s., XXXVII, 173-190.

Jenson, J.W., Keel, T.M., Mylroie, J.R., Mylroie, J.E., Stafford, K.W., Taboroši, D. \& C. Wexel, 2006: Karst of the Mariana Islands: The interaction of tectonics, glacioeustasy and fresh-water/sea-water mixing in island carbonates.- Geological Society of America, Special Paper, 404, 129-138.

Juračić, M., Bakran-Petricioli, T. \& D. Petricioli, 2002: Cessation of karstification due to the sea-level rise? Case study of the Y-cave, Dugi Otok, Croatia.- In: Gabrovšek F. (ed.) Evolution of Karst: From Prekarst to Cessation - Proceedings of the Symposium, $17^{\text {th }}-21^{\text {st }}$ September 2002, Postojna. Založba ZRC, 319-326, Postojna - Ljubljana.

Kelley, K., Mylroie, J.E., Mylroie, J.R., Moore, C., Moore, P.J., Collins, L., Ersek, L., Lascu, I., Roth, M., Passion, R. \& C. Shaw, 2006: Eolianites and Karst Development in the Mayan Riviera, Mexico.- In: Davis, R. L. \& D. W. Gamble (eds.) Proceedings of the $12^{\text {th }}$ Symposium on the Geology of the Bahamas and Other Carbonate Regions, $3^{\text {rd }}-7^{\text {th }}$ June 2004, San Salvador Island, Bahamas. Gerace Research Center, 88-99, San Salvador.
Korbar, T., 2009: Orogenic evolution of the External Dinarides in the NE Adriatic region: a model constrained by tectonostratigraphy of Upper Cretaceous to Paleocene carbonates.- Earth-Science Reviews, 96, 296-312.

Kuk, V., Prelogović, E. \& I. Dragičević, 2000: Seismotectonically Active Zones in the Dinarides.- Geologia Croatica, 53, 2, 295-303.

Labourdette, R., Lascu, I., Mylroie, J.E. \& M. Roth, 2007: Process-like modeling of flank margin caves: From genesis to burial evolution.- Journal of Sedimentary Research, 77, 965-979.

Lace, M.J., 2008: Coastal cave development in Puerto Rico.- Journal of Coastal Research, 24, 2, 508-518.

Lambeck, K. \& A. Purcell, 2005: Sea-level change in the Mediterranean Sea since the LGM: model predictions for tectonically stable areas.- Quaternary Science Reviews, 24, 1969-1988.

Lambeck, K. \& J. Chappell, 2001: Sea level change through the last glacial cycle.- Science, 292, 5517, 697-686.

Lambeck, K., Antonioli, F.A.P. \& S. Silenzi, 2004: Sealevel change along Italian coast for the past 10,000 yr.- Quaternary Science Reviews, 23, 1567-1598.

Moore, P.J., Martin, J.H. \& J.E. Mylroie, 2007: Rapid development of secondary porosity within freshwater lenses of carbonate islands.- Geological Society of America, Abstracts with Programs, 39, 6, 467.

Mylroie, J.E. \& J.R. Mylroie, 2007: Development of the Carbonate Island Karst Model.- Journal of Cave and Karst Studies, 69, 59-75.

Mylroie, J.E. \& J.R. Mylroie, 2009: Caves as geologic indicators, Kangaroo Island, Australia.- Journal of Cave and Karst Studies, 71, 32-47.

Mylroie, J.E., Carew, J.L., Curran, H.A., Martin, J.B., Rothfus, T.A., Sealey, N.E. \& F.D. Siewers, 2008b: Geology of Rum Cay, Bahamas.- A Field Trip Guide, Gerace Research Center, San Salvador Island, Bahamas, pp. 59, San Salvador.

Mylroie, J.E., Mylroie, J.R. \& C.N. Nelson, 2008a: Flank Margin Cave Development in Telogenetic Limestones of New Zealand.- Acta carsologica, 37, 1, 15-40.

Neuendorf, K.K.E., Mehl, J.P., Jr. \& J.A. Jackson (eds.), 2005: Glossary of Geology.- American Geological Institute, pp. 779, Alexandria, Virginia.

Otoničar, B., 2007: Upper Cretaceous to Paleogene forbulge unconformity associated with foreland basin evolution (Kras, Matarsko Podolje and Istria; SW Slovenia and NW Croatia).- Acta carsologica, 36, 1, 101-120. 
Overpeck, J.T., Otto-Bliesner, B.L., Miller, G.H., Muhs, D.R., Alley, R.B. \& J.T. Kiehl, 2006: Paleoclimatic evidence for future ice-sheet instability and rapid sea-level rise.- Science, 311, 5768, 1747-1750.

Panuska, B.C., Mylroie, J.E., Armentrout, D. \& D. McFarlane, 1998: Magnetostratigraphy of Cueva del Aleman, Isla de Mona, Puerto Rico and the species duration of Audobon's Shearwater.- Journal of Cave and Karst Studies, 60, 96-100.

Proctor, C.J., 1988: Sea-level related caves on Berry Head, South Devon.- Cave Science, 15, 2, 39-49.

Raeisi, E. \& J.E. Mylroie, 1995: Hydrodynamic behavior of caves formed in the fresh-water lens of carbonate islands.- Carbonates and Evaporites, 10, 2, 207-214.

Rubinić, J. \& N. Ožanić, 1992: Hidrološke karakteristike Vranskog jezera na otoku Cresu (Hydrological Characteristic of the Vrana Lake on the Island of Cres).- Građevinar, 44, 7, 521-530.

Schmidt, R., Müller, J., Dreschner-Schneider, R., Krisai, R., Szeroczyńska, K. \& A. Barić, 2000: Changes in lake level and trophy at Lake Vrana, a large karstic lake on the Island of Cres (Croatia), with respect to palaeoclimate and anthropogenic impacts during the last approx. 16,000 years.- Journal of Limnology, 59, 2, 113-130.

Schwabe, S.J. \& J.L. Carew, 2006: Blue holes: An inappropriate moniker for water-filled caves in the Bahamas.- In: Davis, R. L. \& D. W. Gamble (eds.) Proceedings of the $12^{\text {th }}$ Symposium on the Geology of the Bahamas and Other Carbonate Regions, $3^{\text {rd }}-7^{\text {th }}$ June 2004, San Salvador Island, Bahamas. Gerace Research Center, 179-187, San Salvador.

Stafford, K.W., Mylroie, J.E., Mylroie, J.R., Jenson, J.W. \& D. Taboroši, 2004: Coves and pocket beaches: Littoral erosion and flank margin caves.- Geological Society of America, Abstracts and Programs, 36, 284.
Surić, M., Richards, D.A., Hoffmann, D.L., Tibljaš, D. \& M. Juračić, 2009: Sea-level change during MIS 5a based on submerged speleothems from the eastern Adriatic Sea (Croatia).- Marine Geology, 262, 62-67.

Waterstrat, W.J., Mylroie, J.E., Owen, A.M. \& J.R. Mylroie, in press: Coastal caves in Bahamian eolian calcarenites: Differentiating between sea caves and flank margin caves using quantitative morphology.Journal of Cave and Karst Studies.

Weber, J., Vrabec, M., Stopar, B., Pavlovčič-Prešeren, P. \& T. Dixon, 2006: The PIVO-2003 experiment: A GPS study of Istria Peninsula and Adria microplate motion, and active tectonics in Slovenia.- In: Pinter, N., Grenerczy, G., Weber, J., Stein, S. \& D. Medak (eds.) The Adria Microplate: GPS Geodesy, Tectonics and Hazards (NATO Science Series IV: Earth and Environmental Sciences). Springer, pp. 305-320, Dordrecht.

Vlahović, I., Tišljar, J., Velić, I. \& D. Matičec, 2005: Evolution of the Adriatic carbonate platform: Palaeogeography, main events and depositional dynamics.- $\mathrm{Pa}$ laeogeography, Palaeoclimatology, Palaeoecology, 220, 3-4, 333-360.

Vrabec, M. \& L. Fodor, 2006: Late Cenozoic tectonics of Slovenia: structural styles at the Northeastern corner of the Adriatic microplate.- In: Pinter, N., Grenerczy, G., Weber, J., Stein, S. \& D. Medak (eds.) The Adria Microplate: GPS Geodesy, Tectonics and Hazards (NATO Science Series IV: Earth and Environmental Sciences). Springer, pp. 151-168, Dordrecht. 
